\title{
DEFINITIONS IN RESEARCH
}

\section{Establishment of working definitions in nocturnal enuresis}

\author{
R J Butler
}

Studies of childhood nocturnal enuresis have traditionally used various criteria both to select children for treatment and measure its outcome. To make comparison possible among studies an agreed set of working definitions are needed. ${ }^{1}$ The figure gives a flow chart by which the terms used in this paper are placed in context.

\section{Inclusion criteria}

The following characteristics of enuretics being studied should be included:

- Age, including the range for acceptance in the study, and the mean and actual age range of those children enrolled

- Number of boys and girls

- Presence or absence of organic disease

- Number of children with associated diurnal enuresis (such children may respond differently to treatment interventions). 'Daytime wetting' requires definition and may be the occurrence of one or more daytime wetting incidents over a two week period

- The severity of bedwetting before treatment. In a review of 32 studies, ${ }^{1}$ only $38 \%$ of papers reported severity: moreover the number of wet nights/week to be included in the study ranged from one to seven. ${ }^{23} \mathrm{~A}$ baseline period of observation is recommended: from
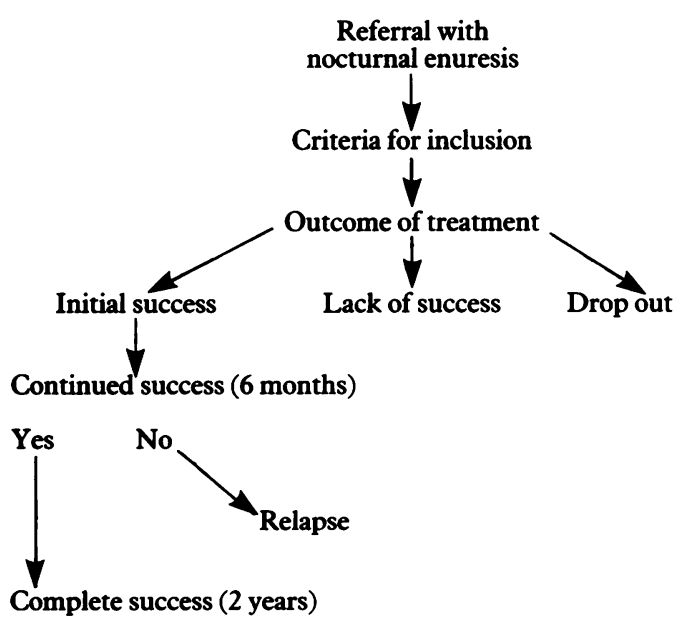

High Royds Hospital, Menston, Ilkley LS29 6AQ

Correspondence to: Dr Butler. the patient's point of view four weeks is probably the maximum length. The suggested inclusion criterion for an individual child is $50 \%$ or more wet nights in a two week period.

When the emphasis of a study is focused on those children who wet less than $50 \%$ of nights and are more difficult to treat, the degree of severity of wetting should be clearly stated.

\section{Initial success}

Initial success is usually described as the achievement of 'an extended number of dry nights'. A working definition requires consideration of two issues: an agreement on what constitutes 'an extended number of dry nights', and the necessity to specify the duration of treatment. I reviewed a range of published reports to clarify the criteria used in practice (table 1). Reports were included in the analysis if they fulfilled the following criteria:

- They were published since 1969 (covering the last 20 years)

- At least 12 children in the study received treatment

- A definition of 'initial success' was included in the methods section

- Treatment was of a 'conditioning' nature (that is, pad and bell, body alarm or dry bed training). These were chosen because of their established effectiveness.

Thirty five studies (90\%) used the completion of a particular number of consecutive nights to define initial success and $27(69 \%)$ selected 14 as that number. Thus 14 consecutive dry nights seems to be an acceptable consensus definition of initial success.

A specified duration of treatment was considered important, as protracted treatment is increasingly influenced by spontaneous remission and thus less confidence can be given to treatment as the effective variable. Two measures of duration of treatment have been used: firstly, a number of trials of the treatment. An arbitrary number of 50 buzzer soundings was selected and if children failed to achieve the initial success criteria during this time they were considered to have failed. ${ }^{24}$ The limitation of such a measure lies in its specificity; it is only applicable to treatment with an enuresis alarm. Secondly, number of weeks of treatment. This is the most common method, and table 2 summarises the studies according to duration of 
Table 1 Criteria for successful treatment of enuresis used in 42 studies

\begin{tabular}{|c|c|c|c|c|}
\hline $\begin{array}{l}\text { Study and } \\
\text { method used }\end{array}$ & $\begin{array}{l}\text { Year } \\
\text { of } \\
\text { publication }\end{array}$ & $\begin{array}{l}\text { Country } \\
\text { of } \\
\text { origin }\end{array}$ & $\begin{array}{l}\text { Definition } \\
\text { of initial } \\
\text { success } \\
\text { (No of } \\
\text { consecutive dry } \\
\text { nights) }\end{array}$ & $\begin{array}{l}\text { Duration of } \\
\text { treatment unless } \\
\text { otherwise stated }\end{array}$ \\
\hline $\begin{array}{l}\text { Pad and bell: } \\
\text { Baker } \\
\text { Berg et al }\end{array}$ & $\begin{array}{l}1969 \\
1982\end{array}$ & $\begin{array}{l}\text { USA } \\
\text { UK }\end{array}$ & $\begin{array}{l}14 \\
\text { On average <once } \\
\text { a week in a } \\
\text { four week period }\end{array}$ & $\begin{array}{l}10 \\
16 \text { (average) }\end{array}$ \\
\hline $\begin{array}{l}\text { Bollard and Nettelbeck } \\
\text { Butler } e t a l^{7} \\
\text { Butler } e t a l^{8} \\
\text { Collins }{ }^{9} \\
\text { Dische } \\
\text { Dische } e t a l^{11} \\
\text { Fielding }{ }^{2} \\
\text { Fielding }{ }^{12} \\
\text { Finley } e t a l^{13} \\
\text { Fordham and Meadow }{ }^{14} \\
\text { Forsythe and Redmond } \\
\text { Goel } e t a l^{16} \\
\text { Houts } e t a l^{17} \\
\text { Jehu } e t \text { al } \\
\text { McConaghy } \\
\text { Netley } e t a l^{20} \\
\text { Sacks and DeLeon } \\
\text { Taylor and Turner }\end{array}$ & $\begin{array}{l}1981 \\
1988 \\
1989 \\
1973 \\
1971 \\
1983 \\
1980 \\
1985 \\
1982 \\
1989 \\
1970 \\
1984 \\
1986 \\
1977 \\
1969 \\
1984 \\
1978 \\
1975\end{array}$ & $\begin{array}{l}\text { Australia } \\
\text { UK } \\
\text { UK } \\
\text { USA } \\
\text { UK } \\
\text { UK } \\
\text { UK } \\
\text { UK } \\
\text { USA } \\
\text { UK } \\
\text { UK } \\
\text { UK } \\
\text { USA } \\
\text { UK } \\
\text { Australia } \\
\text { Canada } \\
\text { USA } \\
\text { UK }\end{array}$ & $\begin{array}{l}14 \\
14 \\
14 \\
10 \\
21 \\
21 \\
14 \\
14 \\
14 \\
42 \\
28 \\
<\text { Four in } 28 \\
14 \\
14 \\
14 \\
2 \text { month } \\
13 \\
\text { No more than one } \\
\text { 'accident in } 28 \text { nights }\end{array}$ & $\begin{array}{l}20 \\
16 \\
16 \\
8 \\
52 \\
\text { No limit } \\
12 \\
14 \\
\text { No limit } \\
16 \text { (extended to six months) } \\
30 \\
20 \\
16 \\
16 \\
10 \\
\text { Not given } \\
\text { Not given } \\
\text { Not given }\end{array}$ \\
\hline $\begin{array}{l}\text { Turner et } a l^{23} \\
\text { Wagner et } a l^{24} \\
\text { Wagner and Matthews } \\
\text { Young and Morgan }\end{array}$ & $\begin{array}{l}1970 \\
1982 \\
1985 \\
1972 a\end{array}$ & $\begin{array}{l}\text { UK } \\
\text { USA } \\
\text { USA } \\
\text { UK }\end{array}$ & $\begin{array}{l}14 \\
14 \\
14 \\
14\end{array}$ & $\begin{array}{l}4 \\
14 \\
12 \\
\text { Not given }\end{array}$ \\
\hline $\begin{array}{l}\text { Body alarm: } \\
\text { Arroe and Barner-Rasmussen }{ }^{27} \\
{ }^{*} \text { Butler } e t \text { al } \\
{ }^{*} \text { Fordham and Meadow } \\
\text { Moffat } e t l^{28} \\
\text { Shapiro }\end{array}$ & $\begin{array}{l}1979 \\
1989 \\
1989 \\
1987 \\
1985\end{array}$ & $\begin{array}{l}\text { Denmark } \\
\text { UK } \\
\text { UK } \\
\text { Canada } \\
\text { USA }\end{array}$ & $\begin{array}{l}14 \\
14 \\
42 \\
14 \\
21\end{array}$ & $\begin{array}{l}1-11 \text { (months) } \\
16 \\
16 \text { (extended to six months) } \\
\text { Not given } \\
5-36 \text { (months) }\end{array}$ \\
\hline $\begin{array}{l}\text { Dry bed training: } \\
\text { Azrin } e t a l^{30} \\
\text { Azrin } e t a l^{31} \\
\text { Azrin and Thienes } \\
\text { Besalel-Azrin } e t a l^{33} \\
{ }^{*} \text { Bollard and Nettelbeck } \\
\text { Bollard and Nettelbeck } \\
\text { Bollard } e t a l^{34} \\
\text { Bollard and Woodroffe } \\
\text { Breit } e t \text { al } \\
{ }^{*} \text { Butler } e t a l^{73} \\
\text { Doleys } e t a l^{38} \\
\text { Griffiths } e t a l^{39} \\
\text { Keating } e t a l^{40}\end{array}$ & $\begin{array}{l}1974 \\
1979 \\
1978 \\
1980 \\
1981 \\
1982 \\
1982 \\
1977 \\
1984 \\
1988 \\
1977 \\
1982 \\
1983\end{array}$ & $\begin{array}{l}\text { USA } \\
\text { USA } \\
\text { USA } \\
\text { USA } \\
\text { Australia } \\
\text { Australia } \\
\text { Australia } \\
\text { Australia } \\
\text { USA } \\
\text { UK } \\
\text { USA } \\
\text { UK } \\
\text { USA }\end{array}$ & $\begin{array}{l}14 \\
14 \\
14 \\
14 \\
14 \\
14 \\
14 \\
14 \\
14 \\
14 \\
14 \\
14 \\
14\end{array}$ & $\begin{array}{l}\text { Not given } \\
\text { Not given } \\
\text { Not given } \\
6 \text { (months) } \\
20 \\
20 \\
8 \\
\text { Not given } \\
\text { Not given } \\
16 \\
6 \\
22 \\
25\end{array}$ \\
\hline
\end{tabular}

${ }^{*}$ Study design same as that in pad and bell study.

Table 2 Studies summarised according to number of weeks of treatment

\begin{tabular}{lllll}
\hline $\begin{array}{l}\text { No of weeks } \\
\text { of treatment }\end{array}$ & Pad and bell & Body alarm* & $\begin{array}{l}\text { Dry bed } \\
\text { training* }\end{array}$ & Total \\
\hline $4-6$ & 1 & 0 & 1 & 2 \\
8 & 1 & 0 & 1 & 2 \\
10 & 2 & 0 & 0 & 2 \\
12 & 2 & 0 & 0 & 2 \\
14 & 2 & 0 & 0 & 2 \\
16 & 6 & 0 & 0 & 6 \\
20 & 2 & 0 & 1 & 3 \\
Other & 2 & 2 & 3 & 7 \\
Not given & 7 & 1 & 5 & 13 \\
\hline Total & 25 & 3 & 11 & 39
\end{tabular}

*The two studies comparing body worn alarm with pad and bell, and the two studies comparing dry bed training with pad and bel are included in the pad and bell column.

treatment. A third of the studies failed to specify duration of treatment. In the others a wide variety of treatment lengths (from four weeks to 36 months) were used, with 16 weeks as the most common.

An average course of treatment for the pad and bell is five to eight weeks. ${ }^{41}$ Thus studies in which treatment lasts less than eight weeks exclude all but the fast responders, and consequently underestimate the success rate. As the average annual spontaneous cure rate between 5 and 9 years is $14 \%$, however, and between 10 and 19 years is $16 \%$, the longer the treatment the less confidence that can be attributed to the treatment itself. Duration of treatment might therefore be considered appropriate within a range of 12 to 20 weeks. As 16 has been used most frequently (nine studies from five different centres), this has been selected as the preferred option.

Thus a proposed definition of initial success is the achievement of 14 consecutive dry nights within a 16 weeks' treatment period. Conversely, lack of success would be accepted if treatment failed to meet these criteria.

\section{'Drop outs'}

A third possible outcome is premature stopping of treatment. This may occur for a number of reasons which have been classified as 'drop outs' for the reasons given below.

(i) Failure to attend. This generally means that after an initial appointment, a number of subsequent appointments are missed without notice or explanation. 
Reasonable clinical practice suggests that failing to attend on two consecutive occasions can be considered as dropping out. Research protocols need to specify the degree and type of contact. There is an assumption that missed appointments mean that the patient 'has voted with his feet'. There are, however, many variables associated with missed appointments, and it may be that some children stop attending because bladder control has been achieved and appointments are considered unnecessary. For example, in one investigation $19 \%$ of the children stopped treatment prematurely because they had become dry. ${ }^{44} \mathrm{~A}$ further reason for non-attendance is the practical difficulty of getting to clinic appointments. Research investigations should attempt to delineate whether drop outs through failure to attend are successes (either using the initial success criteria or parent imposed criteria) or failures.

(ii) The family wishes to discontinue treatment. For whatever reasons, if the child and parent wish to withdraw from treatment this is considered a drop out.

(iii) The doctor wishes to discontinue treatment. There may be instances where the doctor takes a clinical decision to stop treatment. This too constitutes a drop out.

(iv) The parents or the child may not accept treatment. ${ }^{12}$ It might be argued that as treatment has yet to be initiated it cannot be viewed as 'premature stopping of treatment' and does not therefore constitute a drop out. Thus a proposed definition of drop out is that, after an initial appointment, two consecutive appointments are missed without notice, or treatment is discontinued by agreement by parent, child, or doctor. Protocols should endeavour to differentiate drop out successes from drop out failures.

\section{Relapse}

Relapse is generally accepted to mean a return to regular bedwetting after a period of being dry. ${ }^{42}$ What, however, constitutes 'regular wetting'? Adoption of the stringent criterion that relapse was a single wet incident in the six months after a treatment success resulted in an $80 \%$ relapse rate. ${ }^{45}$ This suggests that only a small number of children will remain completely free of bedwetting accidents once treated, a result that has been replicated in several studies. ${ }^{96}$ It has been argued, however, that occasional bedwetting accidents after initial success should not be considered relapse on the grounds that (i) occasional bedwetting occurs among 'normal' or non-enuretic children, and (ii) bladder control may continue to be 'vulnerable' for some time and bedwetting may occur at times when the child is ill or under stress. Such lapses of control remit spontaneously and do not predict further relapse, suggesting that a definition of relapse should take this into account. ${ }^{46}$
Table 3 Definitions of relapse used in 24 studies

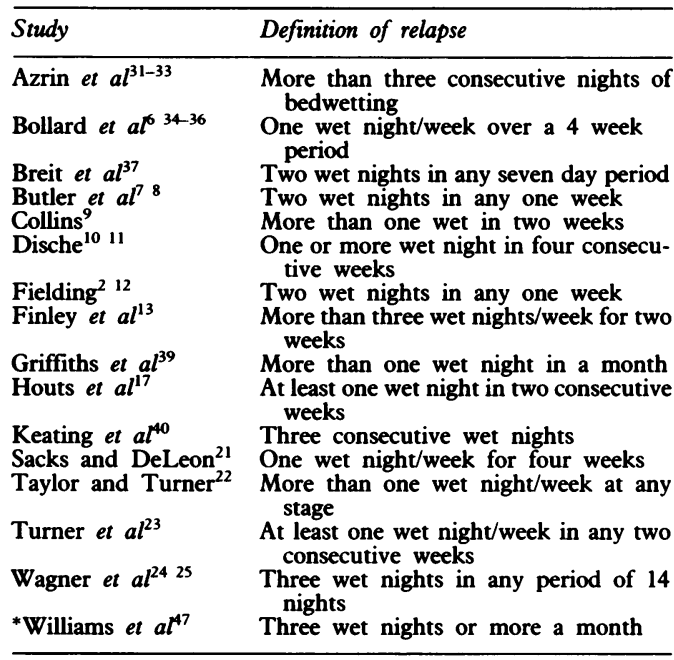

*This is a follow up of the study by Doleys $e t a l .^{38}$

The acceptance of occasional wet nights into a definition of relapse has, however, resulted in a wide variety of definitions (table 3 ). The 16 centres reported 10 different definitions. To examine these, a number of hypothetical cases were put forward. Table 4 shows to what extent relapse was accepted for six different cases using each definition. There was: (i) no unanimity for accepting relapse; (ii) a range of acceptance from more than three wet nights/week for two weeks-indicating no relapse-to more than one wet night/month, in which case relapse was judged to be universal; (iii) difficulty in applying some definitions because of ambiguity.

The most popular definitions were: more than one wet night/week (four centres), and one wet night/week over four weeks (three centres). The creation of an acceptable definition depends on agreeing about: the duration of monitoring, the elapsed time-that is, the length of time for which wet nights are observed-and the number of wet nights.

DURATION OF MONITORING

Nearly all relapses, however defined, occur within the first six months of treatment. ${ }^{11} 214246$ Thus regular monitoring of progress for six months after initial success seems to be good practice. ${ }^{43}$ Relapse during this six month period usually indicates the need for retraining, whereas an absence of relapse might be considered to be continued success. As relapse is uncommon after six months, a two year period of monitoring has been advocated during which the follow up would be less intensive than during the first six months. ${ }^{15}$ Complete success has been suggested to describe those children who do not relapse within two years of their initial success. ${ }^{146}$

\section{ELAPSED TIME}

The options considered could be number of weeks, number of days, or number of consecutive wet nights. 
Table 4 Diagnosis of relapse for each definition for six hypothetical cases

\begin{tabular}{|c|c|c|c|c|c|c|}
\hline \multirow[t]{2}{*}{ Definition } & \multicolumn{6}{|c|}{ No of wet nights/week for four weeks } \\
\hline & $\begin{array}{l}\text { Case } 1 \\
(1,1,1,1)\end{array}$ & $\begin{array}{l}\text { Case } 2 \\
(1,0,6,0,)\end{array}$ & $\begin{array}{l}\text { Case } 3 \\
(0,0,2,0)\end{array}$ & $\begin{array}{l}\text { Case } 4 \\
(1,3,0,0,)\end{array}$ & $\begin{array}{l}\text { Case } 5 \\
(2,2,0,2)\end{array}$ & $\begin{array}{l}\text { Case } 6 \\
(1,1,2,0)\end{array}$ \\
\hline 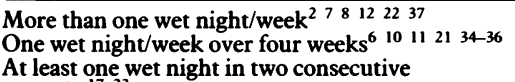 & $\begin{array}{l}\text { No } \\
\text { Yes }\end{array}$ & $\begin{array}{l}\text { Yes } \\
\text { Uncertain }\end{array}$ & $\begin{array}{l}\text { Yes } \\
\text { No }\end{array}$ & $\begin{array}{l}\text { Yes } \\
\text { Uncertain }\end{array}$ & $\begin{array}{l}\text { Yes } \\
\text { Uncertain }\end{array}$ & $\begin{array}{l}\text { Yes } \\
\text { Uncertain }\end{array}$ \\
\hline $\begin{array}{l}\text { weeks } 1723 \\
\text { More than three consecutive wet nights } \\
\text { More than one wet night in two weeks } \\
\text { More than three wet nights/week for }\end{array}$ & $\begin{array}{l}\text { Yes } \\
\text { No } \\
\text { Yes }\end{array}$ & $\begin{array}{l}\text { Yes } \\
\text { Uncertain } \\
\text { Yes }\end{array}$ & $\begin{array}{l}\text { No } \\
\text { No } \\
\text { Yes }\end{array}$ & $\begin{array}{l}\text { Yes } \\
\text { Uncertain } \\
\text { Yes }\end{array}$ & $\begin{array}{l}\text { Yes } \\
\text { Uncertain } \\
\text { Yes }\end{array}$ & $\begin{array}{l}\text { Yes } \\
\text { No } \\
\text { Yes }\end{array}$ \\
\hline two weeks 13 & No & No & No & No & No & No \\
\hline More than one wet night/month ${ }^{39}$ & Yes & $\begin{array}{l}\text { Yes } \\
\text { Yes }\end{array}$ & Yes & Yes & Yes & Yes \\
\hline $\begin{array}{l}\text { Three consecutive wet nights } \\
\text { Three wet nights in any } 14^{4} 5\end{array}$ & $\begin{array}{l}\text { No } \\
\text { No }\end{array}$ & $\begin{array}{l}\text { Yes } \\
\text { Yes }\end{array}$ & $\begin{array}{l}\text { No } \\
\text { No }\end{array}$ & $\begin{array}{l}\text { Uncertain } \\
\text { Yes }\end{array}$ & $\begin{array}{l}\text { Uncertain } \\
\text { Yes }\end{array}$ & $\begin{array}{l}\text { Uncertain } \\
\text { Yes }\end{array}$ \\
\hline Three wet nights or more/month ${ }^{47}$ & Yes & Yes & No & Yes & Yes & Yes \\
\hline
\end{tabular}

Number of weeks

This is the most popular, the possibilities being one week (first definition), two weeks (third, fifth, and sixth definitions) or four weeks (second definition) (table 4). Two definitions (the seventh and tenth) give a month as the elapsed time but this suggests a less precise measure, because of the variable number of days in a month. Extending the time over which the definition applies introduces further complexity. For example, the second definition (one wet night/week over four weeks) might mean that a child who had one dry week but then wetted severely during the other three weeks would not be considered to have relapsed. This indicates that wet nights/week over a number of weeks should be avoided.

\section{Number of days}

Two examples are two wet nights in any seven day period, ${ }^{38}$ and three wet nights in any 14. ${ }^{25}{ }^{26}$ Such definitions seem to emphasise the number of wet nights over a shifting period of time (any seven or 14 consecutive nights), which avoids the problem of number of wet nights/week over a specified period of time. This might provide a more clear cut criterion of relapse.

Number of consecutive wet nights (fourth and eighth definitions)

The merit of this option is that it avoids the need for an elapsed time. Using a number of consecutive nights, however, suggests that a child might be wetting four or five times a week and were these not on consecutive nights a relapse would not have been diagnosed.

The preferred options (without specifying the number of wet nights) might therefore be considered as: more than wet night/week (first definition); more than wet night in two weeks (fifth definition); or one wet night in any 14 (ninth definition).

\section{THE NUMBER OF WET NIGHTS}

The number of wet nights beyond which relapse is indicated must at this stage be a somewhat arbitrary choice. Taking the preferred options the maximum number of wet nights allowed before a relapse would be judged is: first definition-one wet night a week; fifth definition-one wet night over two weeks; or ninth definition-two wet nights in any 14 .

It seems therefore that the first and ninth definitions are in agreement in allowing two wet nights over two weeks or 14 nights. The options then look like this: more than one wet night a week (first definition); more than two wet nights in two weeks; or more than two wet nights in any 14 (ninth definition).

The first option is the most commonly used, but the second and third are consistent with the initial definition of success in using 14 consecutive nights. All three options are sensitive in detecting relapse in the six hypothetical cases (table 4), and indeed options 2 and 3 give identical results.

Taking note of the lack of agreement between workers, the appropriate view might be to adopt option 2, a succinct yet easily applied definition that accepts the occurrence of occasional wet nights. Thus a proposed definition of relapse is more than two wet nights over two weeks.

\section{Summary of definitions}

SEVERITY

For inclusion in a research study a child should have $50 \%$ or more wet nights in two weeks.

INITIAL SUCCESS

The achievement of 14 consecutive dry nights within a 16 week treatment period. As a measure of the effectiveness of treatment the average number of weeks taken to reach the initial criteria of success might be a useful variable.

LACK OF SUCCESS

Failure to meet the initial criteria of success excluding drop outs.

\section{DROP OUTS}

After an initial appointment, two consecutive appointments are missed without notice, or treatment is discontinued by agreement by parents, child, or doctor. The clinician should endeavour to discover whether the drop out was a success or a failure.

RELAPSE

More than two wet nights in two weeks. The 
time between initial success and relapse should be stated.

CONTINUED SUCCESS

No relapse in the six months after initial success.

\section{COMPLETE SUCCESS}

No relapse in the two years after initial success.

I am grateful to the Enuresis Resource and Information Centre (Institute of Child Health, Bristol) for their support and to Pro(Institute of Child Health, Bristol) for their support and to ProMeadow, Roger Morgan, Mary McGraw, John Osborne, Paul Meadow, Roger Morgan, Mary McGraw, John Osborne, Paul
Stallard, Betty Tribe, and Heather Williamson (all of whom are members of the National Enuresis Research Steering Group) for members of the National Enuresis Research Steering Group) for to Amanda Pullan for typing the manuscript.

1 Forsythe WI, Butler RJ. Fifty years of enuretic alarms. Arch Dis Child 1989;64:879-85.

2 Fielding $D$. The response of day and night wetting children and children who wet only at night to retention control training and the enuresis alarm Behav Res Ther 1980;18:305-17.

3 Forrester RM, Stein Z, Susser MW. A trial of conditioning therapy in nocturnal enuresis. Dev Med Child Neurol 1964;6:158-66.

4 Baker BL. Symptom treatment and symptom substitution in enuresis. I Abnorm Psychol 1969;74:42-9.

5 Berg IB, Forsythe I, McGuire R. Response of bedwetting to the enuresis alarm: influence of psychiatric disturbance and maximum bladder capacity. Arch Dis Child 1982;57:394-6.

6 Bollard J, Nettelbeck T. A comparison of DBT and standard urine-alarm conditioning treatment of childhood bedwetting. Behav Res Ther 1981;19:215-26.

7 Butler RJ, Brewin CR, Forsythe WI. A comparison of two approaches to the treatment of nocturnal enuresis and the approaches to the treatment of nocturnal enuresis and the prediction of effectiveness using pre-treatm.
J Child Psychol Psychiatry 1988;29:501-9.

8 Butler RJ, Forsythe WI, Robertson J. A comparative study of the body worn alarm in the treatment of childhood nocturthe body worn alarm in the treatment of childho
nal enuresis. Br $\mathcal{F}$ Clin Pract 1990;44:237-41.

9 Collins RW. Importance of the bladder-cue buzzer contingency in the conditioning treatment for enuresis. $f$ Abnorm gency in the conditioning

10 Dische S. Management of enuresis. BMF 1971;ii:33-6.

1 Dische $S$. Treatment of enuresis with an enuresis alarm. In: Kolvin I, MacKeith RC, Meadow SR, eds. Bladder control and enuresis. London: Heinemann, 1973:211-30.

12 Fielding D. Factors associated with drop-out, relapse and failure in the conditioning treatment of nocturnal enuresis. Behavioural Psychotherapy 1985;13:174-85.

13 Finley WW, Rainwater AJ, Johnson G. Effect of varying alarm schedules on acquisition and relapse parameters in the conditioning treatment of enuresis. Behav Res Ther 1982;20:69-80.

14 Fordham KE, Meadow SR. Controlled trial of standard pad and bell alarm against mini alarm for nocturnal enuresis. Arch Dis Child 1989;64:651-6.

15 Forsythe WI, Redmond A. Enuresis and the electric alarm: study of 200 cases. BMf 1970;i:211-3.

16 Goel KM, Thomson RB, Gibb EM, McAinish TF. Evaluation of nine different types of enuresis alarm. Arch Dis
Child 1984;59:748-53.

17 Houts AC, Petersen JK, Whelan JP. Prevention of relapse in full-spectrum home training for primary enuresis: a com-

ponents analysis. Behaviour Therapy 1986;17:462-9.
Jehu D, Morgan RTT, Turner RK, Jones A. A controlled trial of the treatment of nocturnal enuresis in residential trial of the treatment of nocturnal enuresis in resicen

19 McConaghy N. A controlled trail of imipramine, amphetamine, pad and bell conditioning and random awakening in the treatment of nocturnal enuresis. Med $\mathcal{f}$ Aust 1969;2:237-9.
20 Netley C, Khanna F, McKendry JBJ, Lovering JS. Effects of different methods of treatment of primary enuresis on psychologic functioning in children. Can Med Assoc $\mathcal{F}$ 1984;131:577-9.

21 Sacks S, DeLeon G. Conditioning functional enuresis: follo up after retraining. Behav Res Ther 1983;21:693-4.

22 Taylor PD, Turner RK. A clinical trial of continuous, intermittent and overlearning 'bell and pad' treatment for nocturnal enuresis. Behav Res Ther 1975;13:281-93.

23 Turner RK, Young GC, Rachman S. Treatment of nocturnal enuresis by conditioning techniques. Behav Res The 1970;8:367-81.

24 Wagner W, Johnson SB, Walker D, Carter R, Wittner J. A controlled comparison of two treatments for nocturnal enuresis. 7 Pediatr 1982;101:302-7.

25 Wagner WG, Matthews R. The treatment of nocturnal enuresis: a controlled comparison of two models of urine alarm. Developmental and Behavioural Paediatrics 1985;6:22-6.

26 Young GC, Morgan RTT. Overlearning in the conditionin treatment of enuresis. Behav Res Ther 1972;10:147-51.

27 Arroe M, Barner-Rasmussen P. Treatment of nocturnal enuresis by means of an alarm system worn by the patient. Ugeskr Laeger 1979;141:729-31.

28 Moffat MEK, Kato C, Pless IB. Improvements in self concept after treatment of nocturnal enuresis: randomized concept after treatment of nocturnal enuresis:

29 Shapiro S. Enuresis: treatment and overtreatment. Pediatric Nursing 1985;11:203-7.

30 Azrin NH, Sneed TJ, Foxx RM. Dry-bed training: rapid elimination of childhood enuresis. Behav Res Ther 1974:12:147-56.

31 Azrin NH, Thienes-Hontos P, Besalel-Azrin V. Elimination of enuresis without a conditioning apparatus: an extension by office instruction of the child and parents. Behaviour Therapy 1979;10:14-19.

32 Azrin NH, Thienes PM. Rapid elimination of enuresis by intensive learning without a conditioning apparatus. Behaviour Therapy 1978;9:342-54.

33 Besalel-Azrin V, Azrin NH, Thienes-Hontos P, McMorrow $M$. Evaluation of a parents' manual for training enuretic children. Behav Res Ther 1980;18:358-60.

34 Bollard J, Nettelbeck T. A component analysis of dry bed training for treatment for bedwetting. Behav Res Ther 1982;20:383-90.

35 Bollard J, Nettelbeck T, Roxbee L. Dry-bed training for childhood bedwetting: a comparison of groups with individually administered parent instruction. Behav Res Ther 1982;20:209-17.

36 Bollard RJ, Woodroffe $P$. The effect of parent-administered dry bed training on nocturnal enuresis in children. Behav dry bed training on noctu

37 Breit M, Kaplan SL, Gauthier B, Weinhold C. The dry-bed method for the treatment of enuresis: a failure to duplicate previous reports. Child and Family Behaviour Therapy previous reports.

38 Doleys DM, Ciminero AR, Tollinson JW, Williams CL, Wells KC. Dry bed training and retention control training: a comparison. Behaviour Therapy 1977;8:541-8.

39 Griffiths P, Meldrum C, McWilliam R. Dry-bed training in the treatment of nocturnal enuresis in childhood: a research report. F Child Psychol Psychiatry 1982;23:485-95.

40 Keating JC, Butz RA, Burke E, Heimberg RG. Dry be training without a urine alarm: lack of effort of setting and therapist contact with child. F Behav Ther Exp Psychiatry 1982;14:109-15.

41 Doleys DM. Behavioural treatments for nocturnal enuresis in children: a review of the recent literature. Psychol Bull 1977;84:30-54.

42 Forsythe WI, Redmond A. Enuresis and spontaneous cure rate: study of 1129 enuretics. Arch Dis Child 1974;49. $259-63$.

43 Meadow R. How to use buzzer to cure bed-wetting. $B M \mathcal{T}$ 1977;ii:1073-5.

44 Young GC, Morgan RTT. Reasons for appointment failure among enuretic patients. Community Med 1972;129:23-5. 45 DeLeon G, Mandell W. A comparison of conditioning and psychotherapy in the treatment of functional enuresis. psychotherapy in the treatme

46 Dische $S$, Yule W, Corbett J Hand D. Childhood nocturnal enuresis: factors associated with outcome of treatment with an enuresis alarm. Dev Med Child Neurol 1983;25:67-80.

47 Williams CL, Doleys DM, Ciminero AR. A two year follow up of enuretic children treated with dry-bed training. $\mathcal{f}$ Behav Ther Exp Psychiatry 1978;9:285-6. 